\title{
HUBUNGAN POLA KONSUMSI MAKANAN SUMBER PROTEIN, LEMAK DAN AKTIFITAS Sedentary DENGAN STATUS GIZI LANSIA ANGGOTA BINAAN POSYANDU LANSIA DI KELURAHAN TALISE WILAYAH KERJA PUSKESMAS TALISE
}

\author{
ABSTRAK \\ Abd. Farid Lewa \\ Bagain Keperawatan Politeknik Kesehatan Kementerian Kesehatan Palu
}

Latar Belakang : lansia cenderung memiliki pola konsumsi yang tidak baik yaitu kurangnya asupan serat dan tinggi konsumsi makanan berlemak. Selain itu pada lansia juga memiliki status gizi yang tidak normal diakibatkan karena terjadinya penurunan fungsi tubuh. Lansia memiliki aktifitas atau perilaku yang kurang bergerak (sedentary), sehingga membuat lansia rentan terhadap berbagai penyakit. Metode Penelitian : jenis penelitian analitik dengan menggunakan pendekatan Cross Sectional.Sampel : 57 responden yaitu lansia anggota binaan posyandu lansia di Kelurahan Talise Wilayah kerja Puskesmas Talise. Hasil penelitian ini menunjukan terdapat hubungan yang signifikan antara pola konsumsi makanan sumber protein dengan status gizi lansia dengan (nilai $p=0,001$ ), terdapat hubungan yang signifikan antara pola konsumsi makanan sumber lemak dengan status gizi lansia dengan ( nilai $p=0,000$ ), dan terdapat hubungan yang signifikan aktifitas sedentarydengan status gizi lansia (nilai $\mathrm{p}=0,009$ ). Kesimpulan : ada hubungan bermakna pola konsumsi makanan sumber protein dengan status gizi lansia. Ada hubungan bermakna pola konsumsi makanan sumber lemak dengan status gizi lansia Ada hubungan aktifitas sedentary dengan status gizi lansia. Saran : bagi petugas kesehatan Puskesmas Talise untuk lebih proaktif dalam memberikan penyuluhan kepada lansia, khususnya mengenai upaya perbaikan gizi pada lansia.

Kata kunci : Pola Konsumsi Makanan Sumber Protein, Pola Konsumsi Makanan Sumber Lemak,Aktifitas Sedentary dan Status Gizi Lansia.

\section{PENDAHULUAN}

Struktur penduduk dunia termasuk Indonesia saat ini menuju proses penuaan yang ditandai dengan meningkatnya jumlah dan proporsi penduduk lanjut usia (lansia). Proporsi penduduk lansia di Indonesia mengalami peningkatan cukup signifikan selama 30 tahun terakhir dengan populasi 5,3 juta jiwa pada tahun 1971 (4,48\% dari total keseluruhan penduduk Indonesia) menjadi 19,3 juta pada tahun 2009 (8,37\% dari total keseluruhan penduduk Indonesia). Peningkatan jumlah penduduk lansia ini disebabkan peningkatan angka harapan hidup sebagai dampak dari peningkatan kualitas kesehatan (Komisi Lanjut Usia, 2010). Sruktur masyarakat
Indonesia berubah dari masyarakat atau populasi muda (1971) menjadi populasi yang lebih tua pada tahun 2020 .

Sedangkan di sisi lain dengan adanya pertambahan jumlah lansia ini membawa konsekuensi terutama di sisi kesehatannya yaitu perubahan fisiologis akibat penuaan. Di Indonesia berdasarkan Undang-undang Nomor 13 tahun 1998 tentang Kesejahteraan Lanjut Usia, yang dimaksud dengan lanjut usia adalah penduduk yang telah mencapai usia 60 tahun ke atas. Diseluruh dunia pendudukLansia (usia $60+$ ) tumbuh dengan sangat cepat bahkan tercepat dibanding kelompokusia lainnya. Anggapan yang berkembang selama ini bahwa kelompok lansia adalah lebih 
kepada beban dari pada sebagai sumber daya, yang mana lansia selalu dipersepsikan secara negatif yang hanya bergantung pada keluarga, masyarakat dan negara. Persepsi itu harus dirubah, bagaimana kita harus membuat lanjut usia sebagai aset bangsa yang harus terus diberdayakan (Komisi Lanjut Usia, 2010).

Masalah gizi yang biasanya terjadi pada lansia yaitu gizi kurang dan gizi lebih. Ditemukan persentasi lansia yang tinggal di daerah perkotaan yang mengalami gizi kurang adalah $3,4 \%$, berat badan kurang $28,3 \%$, berat badan lebih $6,7 \%$, obesitas $3,4 \%$ dan berat badan ideal 42,4\% (Darmojo 2009 dalam Oktariyani, 2012).

Aktifitas kini sudah menjadi kebutuhan masyarakat secara luas. Bagaimanapun juga bertambahnya usia tetap berpengaruh terhadap kemampuan beraktifitas. Biasanya mereka melakukan aktifitas untuk menjaga kesehatan tubuhnya, Sebenarnya tidak banyak biaya untuk melakukan aktifitas tersebut, cukup melakukan aktifitas yang rutin, aktifitas fisik secara teratur minimal 30 menit aktivitas sedang pada setidaknya 5 hari perminggu atau 20 menit (WHO dalam Pranama V, 2012).

Kepandaian menyiasati berbagai serangan yang melemahkan kondisi tubuh, seperti berbagai perubahan fisik dan mental juga adanya berbagai penyakit adalah kunci kebahagiaan lansia. Kecenderungan akan pola hidup yang tidak sehat semakin meluas terutama di daerah perkotaan. Contohnya, akan pola makan yang tidak teratur, minimnya atau kurangnya asupan akan serat (sayuran atau buah-buahan), lebih sering atau senang konsumsi makanan yang berlemak dan berkadar garam (natrium) tinggi, pola tidur tidak teratur, dan kurang berolahraga dan berbagai tekanan atau masalah-masalah yang akan memicu stress dan depresi. Semua itu akan semakin membuat lansia akan rentan terhadap penyakit (Wirakusumah, 2000).

Berdasarkan data tersebut maka penulis tertarik untuk melakukan penelitian tentang hubungan asupan protein, lemak, dan aktifitas sedentary dengan status gizi di posyandu lansia anggota binaan posyandu lansia di Kelurahan TaliseWilayah kerja Puskesmas Talise.

\section{BAHAN DAN METODE PENELITIAN}

Jenis penelitian adalah analitik dengan menggunakan pendekatan Cross Sectional. Populasi dalam penelitian ini adalah semua lansia anggota binaan posyandu lansia di Kelurahan Talise Wilayah Kerja Puskesmas Talise yang berjumlah 57 orang. Sampel dalam penelitian ini adalah 57 responden yaitu lansia anggota binaan posyandu lansia di Kelurahan Talise Wilayah Kerja Puskesmas Talise yang memenuhi syarat untuk diteliti. Sampel diperoleh secara non random dengan teknik Total Sampling. Analisis data dilakukan uji statistik dengan menggunakan metode Chi Square $\left(\mathrm{X}^{2}\right)$ dengan uji Pearson ChiSquare pada a 0,05.

\section{HASIL}

Hasil penelitian dalam bentuk data primer diperoleh melalui wawancaralangsung pada responden mengenai pola konsumsi makanan sumber protein, pola konsumsi makanan sumber lemak, aktifitas sedentary dengan status gizi lansia.

\section{Analisis Univariat}

Pada penelitian ini, hasil analisis univariat akan menggambarkan variabel independen yang meliputi pola konsumsi makanan sumber protein, lemak dan aktifitas sedentary dan variabel dependen yaitu status gizi lansia, adalah sebagai 
Tabel 1

Distribusi Frekuensi Pola Konsumsi Makanan Sumber Protein, Lemak, Aktifitas Sedentary dan Status Gizi Lansia Anggota Binaan Posyandu Lansia Kelurahan Talise Wilayah Kerja Puskesmas Talise 2015

\begin{tabular}{lcc}
\hline Sumber Proteinn & $\mathbf{n}$ & $\mathbf{\%}$ \\
Sering & 30 & 52,6 \\
Jarang & 27 & 47,4 \\
Sumber Lemak & & \\
Sering & 25 & 43,9 \\
Jarang & 32 & 56,1 \\
Aktifitas Sedentary & & \\
Sedentary & 36 & 40.4 \\
Tidak Sedentary & 21 & 59.6 \\
Status Gizi & & \\
Tidak Normal & 38 & 66.7 \\
Normal & 19 & 33.3 \\
\hline Total & $\mathbf{5 7}$ & $\mathbf{1 0 0 . 0}$ \\
\hline
\end{tabular}

Sumber : Data primer terolah tahun 2015

Berdasarkan tabel 1 bahwa, kebanyakan lansia sering mengkonsumsi makanan sumber protein yaitu 30 orang (52,6\%), dan kebanyakan lansia jarang mengkonsumsi makanan sumber lemak 32 orang $(56,1 \%)$, sedangkan aktifitas sedentaryyang terbanyak adalah yang sedentary yaitu 36 orang $(40,4 \%)$ dan status gizi lansia yang terbanyak adalah tidak normal yaitu 38 orang $(66,7 \%)$.

\section{Analisis Bivariat}

a. Hubungan Pola Konsumsi Makanan Sumber Protein dengan Status Gizi Lansia

Tabel 2

Distribusi Responden Menurut Pola Konsumsi Makanan Sumber Protein Dengan Status Gizi Lansia

\begin{tabular}{|c|c|c|c|c|c|c|}
\hline \multirow{3}{*}{$\begin{array}{l}\text { Pola Konsumsi } \\
\text { MakananSumber } \\
\text { Protein }\end{array}$} & \multicolumn{4}{|c|}{ Status Gizi Lansia } & \multirow{3}{*}{ Total } & \multirow{3}{*}{$\begin{array}{c}\text { P } \\
\text { Value } \\
\text { ( Chi- } \\
\text { Square) }\end{array}$} \\
\hline & \multicolumn{2}{|c|}{ Normal } & \multicolumn{2}{|c|}{ Tidak Normal } & & \\
\hline & $\mathbf{F}$ & $\%$ & $\mathbf{F}$ & $\%$ & & \\
\hline Sering & 26 & 86,7 & 4 & 13,3 & 30 & \\
\hline Jarang & 12 & 44,4 & 15 & 55,6 & 27 & 0,001 \\
\hline Jumlah & 38 & 66,7 & 19 & 33,3 & 57 & \\
\hline $\begin{array}{l}\text { Sumber: Data primer } \\
\text { Pada tabel. } \\
\text { bahwa lansia yang } \\
\text { makanan sumber } \\
\text { mempunyai kecen }\end{array}$ & $\begin{array}{l}\text { rolah ta } \\
\text { men } \\
\text { pola } \\
\text { protein } \\
\text { erungan }\end{array}$ & $\begin{array}{l}2015 \\
\text { ukkan, } \\
\text { isumsi } \\
\text { sering } \\
\text { untuk }\end{array}$ & $\begin{array}{l}86,7 \\
\text { gizir } \\
\text { yan } \\
\text { sum }\end{array}$ & $\begin{array}{l}\text { diban } \\
\text { tidak } \\
\text { nemilik } \\
r \quad \text { pro }\end{array}$ & $\begin{array}{l}\text { ing lan } \\
\text { ormal. } \\
\text { pola kc } \\
\text { einjaran }\end{array}$ & $\begin{array}{l}\text { yang st } \\
\text { angkan la } \\
\text { msi maka } \\
\text { kemungki }\end{array}$ \\
\hline
\end{tabular}


berstatus gizi tidak normal sebesar $44,4 \%$.

Berdasarkan hasil uji "Chi Square" nilai $p=0,001(p<0,05)$ berarti secara statistik ada hubungan yang bermakna antara pola konsumsi makanan sumber protein dengan status gizi lansia. Dengan nilai Ratio Prevalence
$(\mathrm{RP})=1,98$ yang artinya lansia yang pola konsumsi makanan sumber protein sering akan memiliki status gizi normal 1,98 kali dibanding yang pola konsumsi makanan sumber protein jarang.

b. Hubungan Pola Konsumsi Makanan Sumber Lemak dengan Status Gizi Lansia

Tabel 3

Distribusi Responden Menurut Pola Konsumsi Makanan Sumber Lemak Dengan Status Gizi Lansia

\begin{tabular}{|c|c|c|c|c|c|c|}
\hline \multirow{3}{*}{$\begin{array}{l}\text { Pola Konsumsi } \\
\text { MakananSumber } \\
\text { Lemak }\end{array}$} & \multicolumn{4}{|c|}{ Status Gizi Lansia } & \multirow{3}{*}{$\begin{array}{c}\text { Total } \\
\mathbf{N}\end{array}$} & \multirow{3}{*}{$\begin{array}{c}\mathbf{P} \\
\text { Value } \\
\text { ( Chi-Square) }\end{array}$} \\
\hline & \multicolumn{2}{|c|}{ Normal } & \multicolumn{2}{|c|}{ Tidak Normal } & & \\
\hline & $\mathbf{F}$ & $\%$ & $\mathbf{F}$ & $\%$ & & \\
\hline Sering & 25 & 100 & 0 & 0 & 25 & 0,000 \\
\hline Jarang & 13 & 40,6 & 19 & 59,4 & 32 & \\
\hline Jumlah & 38 & 66,7 & 19 & 33,3 & 57 & \\
\hline
\end{tabular}

Sumber : Data primer terolah tahun 2015 Pada tabel. 3 menunjukkan, bahwa lansia yang pola konsumsi makanan sumber lemak sering mempunyai kecenderungan untuk memiliki status gizi normal sebesar $100 \%$ dibanding lansia yang status gizinya tidak normal. Sedangkan lansia yang memiliki pola konsumsi makanan sumber lemak jarang kemungkinan berstatus gizi tidak normal sebesar 40,6\%.

Berdasarkan hasil uji "Chi Square" nilai $p=0,000(p<0,05)$ berarti secara statistik ada hubungan yang bermakna antara pola konsumsi makanan sumber lemak dengan status gizi lansia. Dengan nilai Ratio Prevalence $(R P)=2,5$ yang artinya lansia yang pola konsumsi makanan sumber lemak sering akan memiliki status gizi normal 2,5 kali dibanding yang pola konsumsi makanan sumber lemak jarang.

\section{c. Hubungan Aktivitas Sedentary Dengan Status Gizi Lansia}


Tabel 4

Distribusi Responden Menurut Aktifitas Sedentary Dengan Status Gizi Lansia

\begin{tabular}{|c|c|c|c|c|c|c|}
\hline \multirow{3}{*}{ Aktifitas Sedentary } & \multicolumn{4}{|c|}{ Status Gizi Lansia } & \multirow{3}{*}{$\begin{array}{c}\text { Total } \\
\mathbf{N}\end{array}$} & \multirow{3}{*}{$\begin{array}{c}\text { P Value } \\
\text { (Pearson Ch } \\
\text { Square) }\end{array}$} \\
\hline & \multicolumn{2}{|c|}{ Normal } & \multicolumn{2}{|c|}{ Tidak Normal } & & \\
\hline & $F$ & $\%$ & $F$ & $\%$ & & \\
\hline Tidak Sedentary & 29 & 80,6 & 7 & 19,4 & 36 & \\
\hline Sedentary & 9 & 42,9 & 12 & 57,1 & 21 & 0,009 \\
\hline Jumlah & 38 & 66,7 & 19 & 33,3 & 57 & \\
\hline
\end{tabular}

Sumber : Data primer terolah tahun 2015

Pada tabel. 5 menunjukkan, bahwa lansia yang aktifitas tidak sedentary mempunyai kecenderungan untuk memiliki status gizi normal sebesar $80,6 \%$ dibanding lansia yang status gizinya tidak normal. Sedangkan lansia yang memiliki aktifitas sedentary kemungkinan berstatus gizi tidak normal sebesar $57,1 \%$.

Berdasarkan hasil uji "Chi Square" nilai $p=0,009 \quad(p<0,05)$ berarti secara statistik ada hubungan yang bermakna antara aktifitas fisik dengan status gizi lansia. Dengan nilai Ratio Prevalence $(\mathrm{RP})=1,88$ yang artinya lansia yang mempunyai aktifitas fisik tidak sedentary akan memiliki status gizi normal 1,88kali dibanding yang memilki aktifitas sedentary.

\section{PEMBAHASAN}

1. Hubungan Pola Konsumsi Makanan Sumber ProteinDengan Status Gizi Lansia

Hasil analisis univariat menunjukkan, bahwa lansia yang memiliki pola konsumsi makanan sumber protein sering lebih banyak dibanding yang jarang (tabel. 1). Sedangkan hasil analisis bivariat menunjukkan bahwa, lansia yang pola konsumsi makanan sumber protein sering mempunyai kecenderungan untuk memiliki status gizi normal dibanding lansia yang pola makannya jarang.

Menurut peneliti, hal ini disebabkan karena makanan sumber protein baik protein hewani maupun protein nabati mudah didapatkan disekitaran tempat tinggal responden dengan harga terjangkaubagi masyarakat kelurahan Talise. Fungsi utama dari protein adalah membangun dan memelihara jaringan tubuh. Protein juga merupakan salah satu zat gizi sumber energi. Sehingga apabila seseorang mampu menyelenggarakan zat gizi yang adekuat, zat gizi yang telah dikonsumsi tersebut akan digunakan tubuh untuk mencapai status gizi yang optimal (Almatsier, 2009).

Berdasarkan analisis statistik ada hubungan bermakna antara pola konsumsi makanan sumber protein dengan status gizi lansia. Dan hasil penelitian juga menunjukkan, bahwa orang yang pola konsumsi sumber proteinnya sering memiliki peluang untuk mengalami status gizi normal 1,98 kali dari pada orang yang pola konsumsi makanan sumber proteinnya jarang.

Hal tersebut sejalan dengan penelitian yang dilakukan oleh Setiani (2011) dan Rahmianti (2014) yang melihat adanya hubungan konsumsi protein dengan status gizi lansia. 
2. Hubungan Pola Konsumsi Makanan Sumber LemakDengan Status Gizi Lansia

Hasil analisis univariat menunjukkan, bahwa lansia yang memiliki pola konsumsi makanan sumber lemak sering lebih banyak dibanding yang jarang (tabel.2). Sedangkan hasil analisis bivariat menunjukkan bahwa, semua lansia yang pola konsumsi makanan sumber lemak sering mempunyai kecenderungan untuk memiliki status gizi normal dibanding lansia yang pola makannya jarang.

Menurut asumsi peneliti hal ini dikarenakan kebiasaan makan lansia setempat yang suka mengkonsumsi makanan yang menggunakan bahan pangan sumber lemak yaitu minyak kelapa dan santan. Pada dasarnya penggunaan kalori lansia berkurang seiring menurunnya metabolisme tubuh dan terjadinya peningkatan jumlah lemak pada lansia dipengaruhi oleh aktifitas fisik yang kurang dan tidak diimbangi dengan pengurangan asupan makanan. Akan tetapi pada lansia yang berada di anggota binaan posyandu lansia di kelurahan talise, seringnya konsumsi makanan sumber lemak juga diimbangi dengan aktifitas fisik yang sering. Sehingga tidak terdapat kalori berlebih yang akan menyebabkan penumpukan lemak tubuh.

Berdasarkan analisis statistik ada hubungan bermakna antara pola konsumsi makanan sumber lemak dengan status gizi lansia. Dan hasil penelitian juga menunjukkan,bahwa orang yang pola konsumsi sumber lemaknya sering memiliki peluang untuk mengalami status gizi normal 2,5 kali dari pada orang yang pola konsumsi makanan sumber lemaknya jarang.

Hal ini sejalan dengan penelitian yang dilakukan oleh Elvia (2012) dimana lansia cenderung mengkonsumsi makanan yang mengandung gula, tinggi garam dan tinggi lemak jenuh serta rendah sayuran dan serat, hal ini dikarenakan lansia mengalami penurunan indera pengecap dan perasa sehingga lansia sering mengalami masalah gizi baik gizi lebih maupun gizi kurang.

\section{Hubungan Aktifitas Dengan Status Gizi Lansia}

Sedentary Hasil analisis univariat menunjukkan, bahwa lansia yang memiliki aktifitas fisik tidak sedentary lebih banyak dibandingkan yang memilki aktifitas sedentary (tabel 3). Sedangkan hasil analisis bivariat menunjukkan bahwa, lansia yang memilki aktifitas tidak sedentary mememiliki kecenderungan status gizi normal dibandingkan lansia yang memilki aktifitas sedentary.

Menurut asumsi peneliti adanya responden yang memilki aktifitas sedentary berkaitan dengan kemampuan lansia yang sudah terbatas dibuktikan dengan jumlah aktifitas sedentary responden yang rata-rata memiliki aktifitas sedentary yang $>4$ jam/hari dikarenakan aktifitas fisik yang sudah menurun sejalan dengan bertambahnya usia. Juga pendidikan yang rendah serta terlihat banyak lansia yang menjadi responden sudah tidak bekerja lagi sehingga para lansia biasanya lebih banyak menghabiskan waktunya dengan hanya berdiam dirumah dengan melakukan hal-hal yang tidak banyak bergerak. Seseorang yang sering melakukan aktifitas fisik akan mengakibatkan seimbangnya antara jumlah energi yang dikonsumsi dari makanan dengan jumlah pengeluaran kalori akibat aktivitas fisik (olahraga) yang dilakukan. Aktivitas fisik yang dilakukan manusia memerlukan energi dan zat-zat gizi. Apa bila kebutuhan energi dan zat-zat gizi tersebut sebanding dengan kadar aktivitas fisik yang dilakukan maka seseorang akan cenderung memilki status gizi normal.

Berdasarkan analisis statistik ada hubungan bermakna antara aktifitas sedentary dengan status gizi lansia. Dan hasil penelitian juga menunjukkan,bahwa 
orang yang tidak melakukan aktifitas sedentary memiliki peluang untuk mengalami status gizi normal 1,88 kali dari pada orang yang melakukan aktifitas sedentary.

Hal ini sejalan dengan penelitian yang dilakukan oleh Yoga (2014) yang menemukan adanya hubungan antara aktifitas fisik dengan status gizi lansia

\section{KESIMPULAN}

1. Pola konsumsi makanan sumber protein dan lemak lansia di Anggota Binaan Posyandu Lansia Di Kelurahan Talise Wilayah Kerja Puskesmas Talise tergolong sering.

2. Aktivitas fisik lansia dianggota binaan posyandu lansia di kelurahan talise wilayah kerja puskesmas talise.karya, sebagian besar memiliki aktivitas fisik dengan kategori tidak sedentary.

3. Terdapat hubungan antara Hubungan Pola Konsumsi Makanan Sumber Protein, Lemak dan Aktifitas Sedentary Dengan Status Gizi Lansia Anggota Binaan Posyandu Lansia Di Kelurahan Talise Wilayah Kerja Puskesmas Talise.

\section{SARAN}

Posyandu lansia hendaknya memberikan edukasi lebih serta membina lansia tentang harus sadar dan mulai merubah gaya hidup yang tidak aktif atau jarang bergerak menjadi aktif dengan kegiatan-kegiatan rutin atau olahraga fisik yang ringan dilakukan dirumah untuk lebih menyegarkan tubuh di usia senja serta lebih memperhatikan akan pola makan ataupun konsumsi pangan lansia

\section{DAFTAR PUSTAKA}

Almatsier,

S. 2009. PrinsipDasarllmuGizi:Gramedia PustakaUtama Jakarta
Arisman. 2004. Gizi Dalam Daur Kehidupan:buku ajar ilmu gizi. EGC: Jakarta

Elvia,N. Siregar,M,A. Siagian,A. 2013. Gambaran pola konsumsi pangan dan pola penyakit pada usia lanjut di wilayah kerja puskesmas tapaktuan kecamatan tapaktuan kabupaten aceh selatan tahun 2012. Medan : Universitas Sumatera Utara (online). Jurnal.usu.ac.id.

Kemenkes RI. 2009. Jurnal Proyeksi Penduduk Indonesia (online). http://www.bappenas.go.id.

(Diakses tgl 01 Oktober 2014)

Komisi Lanjut Usia (KLU). 2010.

ProfilPendudukLanjutUsia (online),

https://agus34drajat.files.wordp ress.com. Diakses tgl 01 Oktober 2014.Jam 20:53 WITA

Oktariyani. 2012. Gambaran Status Gizi Pada Lanjut Usia di Panti Tresna Werdha (PSTW) Budi Mulya 01 dan 03 Jakarta Timur. Depok :Universitas Indonesia (online). (http://lontar.ui.ac.id,diaksestgl 16 Desember 2014. jam 21:47WITA)

Pranama. V, 2012. Hubungan Aktivitas Fisik dengan Tekanan Darah Pada Lansia Hipertensi di Desa Pomahan Kecamatan Pulung Kabupaten Ponorogo (online). (http://lib.umpo.ac.id, Diaksestgl 20 Januari 2015. Jam 22:39 WITA)

Rahmianti. Bahar, B. Yustini.2014. Hubungan Pola Makan, Status Gizi, Dan Interaksi Sosial Dengan Kualitas Hidup Lansia Suku Bugis Di Kelurahan Sapanang Kabupaten Pangkep. Makasar : Universitas Hasanudin

Setiani,D.,S. 2012. Hubungan Riwayat Penyakit, Asupan Protein Dan Faktor-Faktor Lain Dengan 
Status Gizi Peserta Posyandu Lansia Di Kecamatan Grogol Petamburan Jakarta Barat Tahun 2012. Skripsi: Fakultas Kesehatan Masyarakat, Universitas Indonesia.

Wirakusumah, S. 2000. TetapBugar di UsiaLanjut. Trubus Agriwidya : Jakarta
Yoga,M,A,A. 2014. Hubungan Asupan Energi, Protein Dan Aktivitas Fisikdi UPTD Panti Sosial Tresna Werdha Kecamatan Natar Kabupaten Lampung Selatan (online). (http://digilib.unila.ac.id/6672/2/ ABSTRAK.pdf di akses tanggal 20 Januari 2015 